\title{
Perawatan dan Perbaikan Pompa Sentrifugal 800LC-38A untuk Sirkulasi Air Pendingin Pada PLTU
}

\author{
Alifurrahman, Zikri Hamdani, Darman Dapersal Dinar, Menhendry, Yuli Yetri \\ Politeknik Negeri Padang
}

Email: alifurrahman575@gmail.com

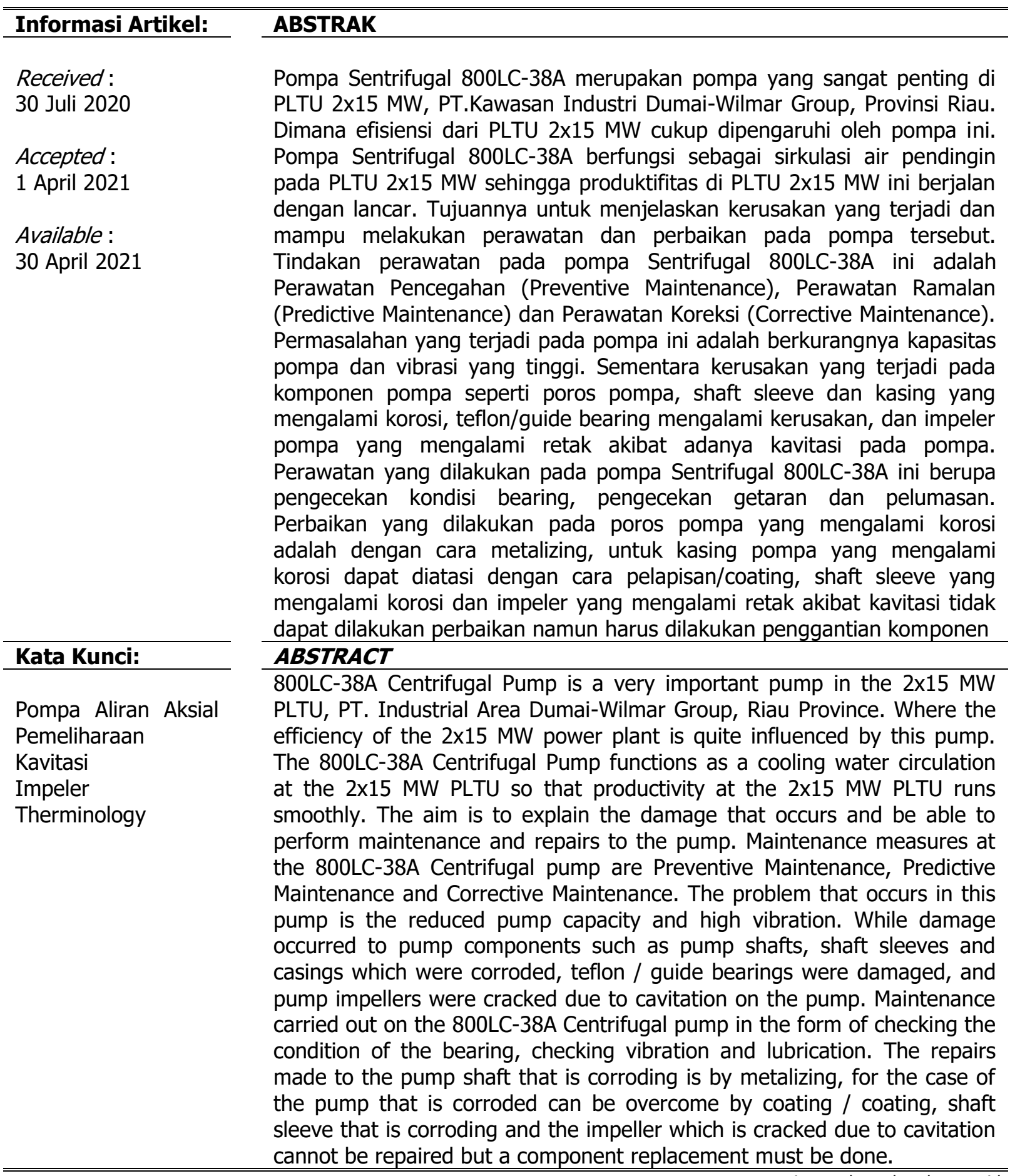




\section{Pendahuluan}

Tenaga listrik kini merupakan landasan bagi kehidupan modern dan ketersediaannya dalam jumlah dan mutu yang cukup menjadi syarat bagi suatu masyarakat yang memiliki taraf kehidupan yang baik. Perkembangan industri yang cukup pesat mendorong para investor untuk bisa memanfaatkan peluang bisnis dalam penyediaan tenaga listrik. Dimana salah satu perusahaan yang kini bisa memanfaatkan peluang tersebut adalah PT.Kawasan Industri Dumai (PT.KID) yang mempunyai pembangkit listrik tenaga uap (Power Station Plant 2X15 MW) terbesar yang ada di Kawasan Industri Dumai, dengan pembangkit turbin tenaga uap, dimana bahan bakar bersumber dari batu bara.

Pembangkit listrik tenaga uap (Power Station Plant 2x15 MW) menggunakan pompa yang berfungsi sebagai media supply air untuk sirkulasi pada PLTU 2x15 MW. Pompa ini mengalirkan air pendingin berupa air laut ke kondensor. Di dalam kondensor air laut ini digunakan untuk proses kondensasi yaitu mengembalikan uap buangan (exhaust steam) dari turbin ke fase cairnya agar dapat dipompakan kembali ke boiler dan digunakan kembali sehingga produktivitas pada pembangkit listrik tenaga uap ini berjalan dengan lancar.

Oleh karena hal itu dibutuhkan tenaga khusus yang terampil dan berpengalaman luas untuk melakukan pengoperasian maupun perawatan terhadap alat tersebut. Untuk menjaga performa dari pompa ini sebagai alat yang penting pada PLTU 2x15 MW agar selalu dalam kondisi optimal, maka prosedur pengoperasian dan pemeliharaannya harus sangat diperhatikan. Karenakan pompa ini adalah unit yang sangat penting dan efisiensi dari produktifitas di PLTU 2x15 cukup dipengaruhi oleh pompa ini dimana perawatan dan perbaikan pompa ini perlu dilakukan untuk menjaga kelangsungan proses produksi pada PLTU 2x15 MW dan untuk memperpanjang usia kegunaan unit ini.

Adapun fungsi dari pompa sentrifugal 800LC-38A ini adalah untuk sirkulasi air pendingin pada PLTU 2x15 MW. Pompa ini mengalirkan air pendingin berupa air laut ke kondensor, di dalam kondensor air laut ini digunakan untuk proses kondensasi yaitu mengembalikan uap buangan (exhaust steam) dari turbin ke fase cairnya agar dapat dipompakan kembali ke boiler dan digunakan kembali sehingga produktivitas pada PLTU 2x15 MW ini berjalan dengan lancar.

\section{METODOLOGI PENELITIAN}

Adapun langkah-langkah dalam perawatan dan perbaikan Pompa Sentrifugal 800LC-38A yaitu seperti diagram di bawah ini. 


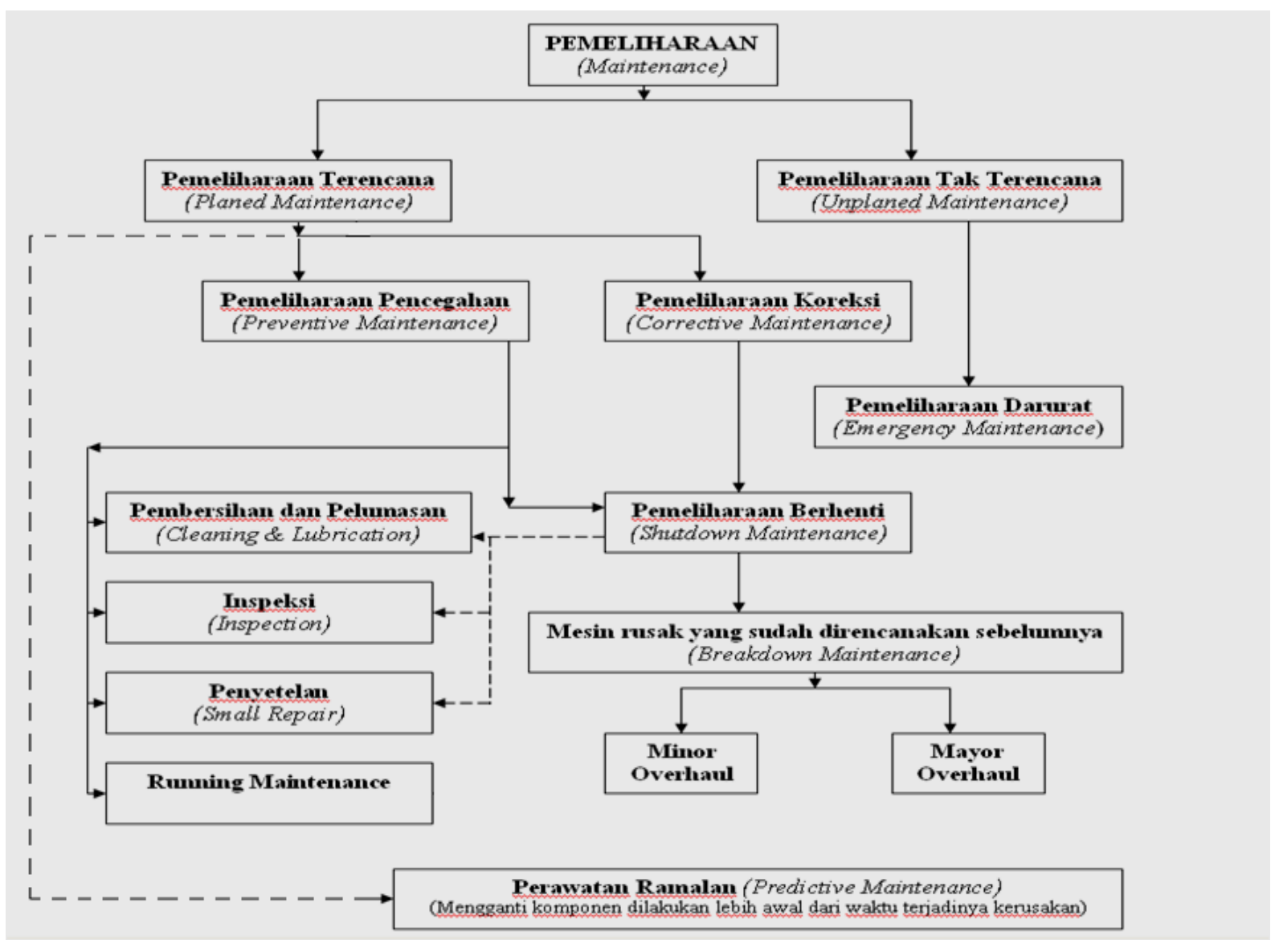

Gambar 1. Skema Perawatan dan Perbaikan

\section{ALAT DAN BAHAN}

Alat-alat yang dipakai adalah Pompa Sentrifugal 800LC-38A, sedangkan bahan yang diperlukan adalah oil pelumas. Untuk lebih jelasnya tentang Pompa Sentrifugal 800LC38A dapat dilihat pada Gambar 2. 
Alifurrahman, Zikri Hamdani, Darman Dapersal Dinar, Menhendry, Yuli Yetri

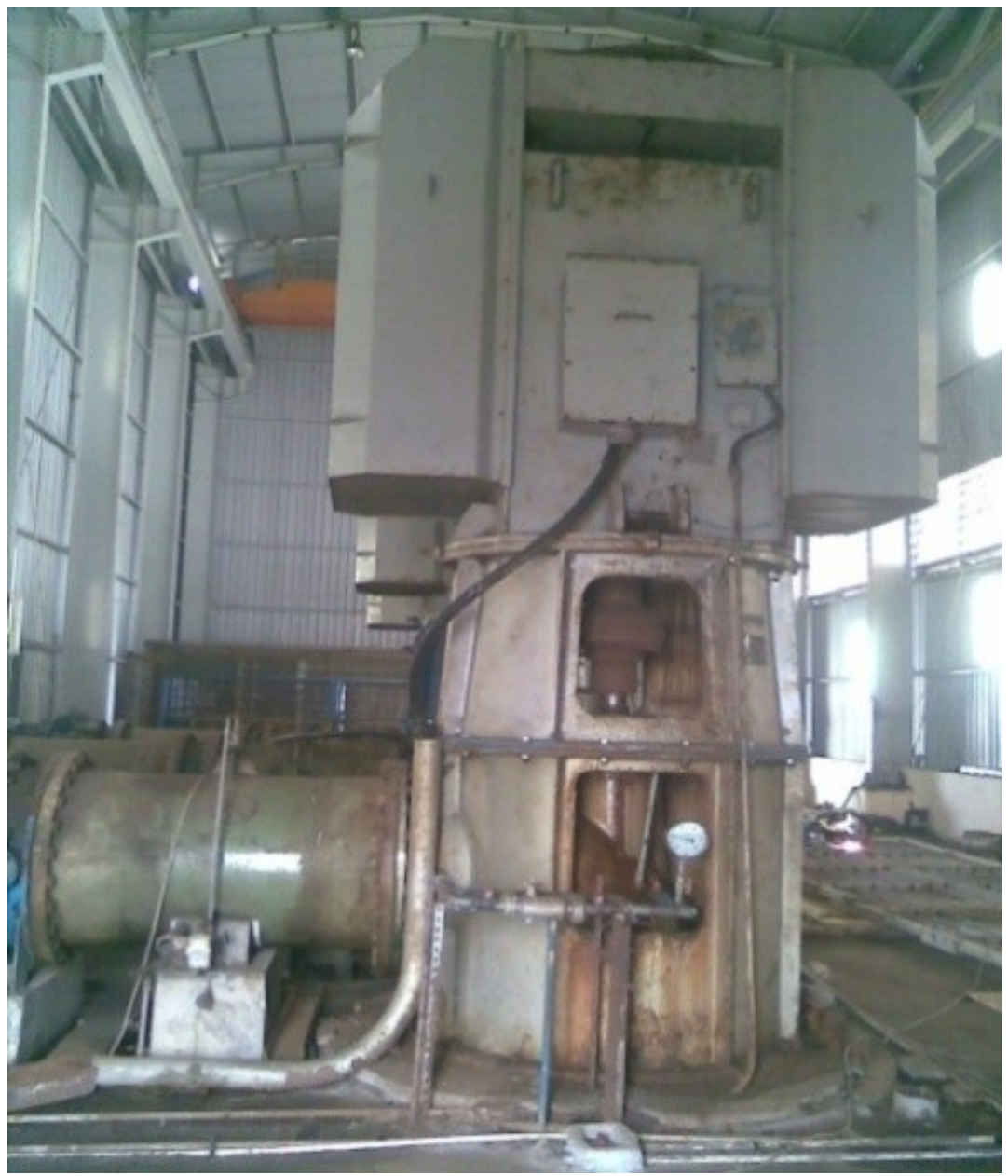




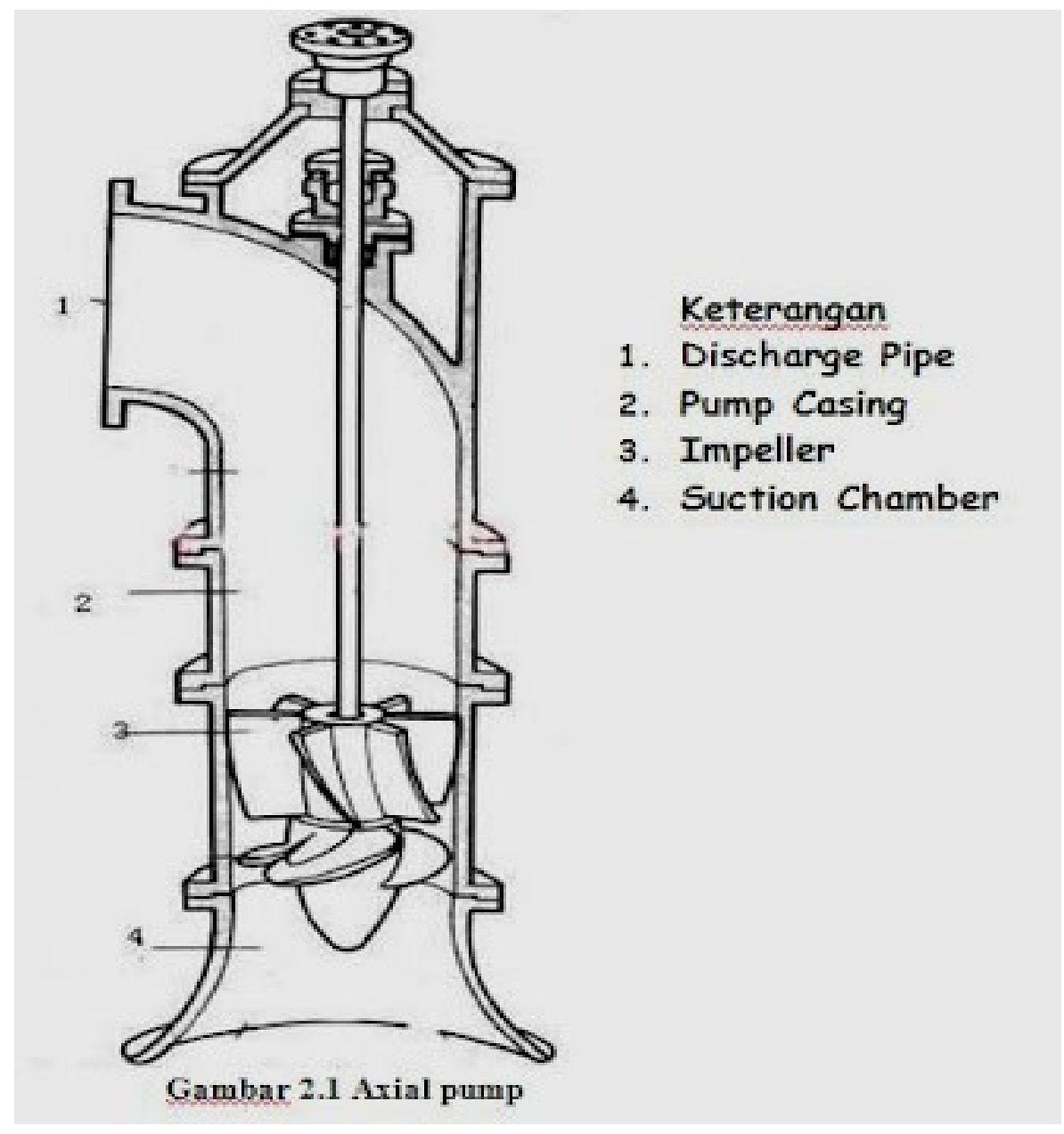

Gambar 2. Pompa Sentrifugal 800LC-38A

\section{HASIL}

\subsection{Pompa Sentrifugal 800LC-38A}

Pompa Sentrifugal berfungsi untuk pemompaan air dalam berbagai penggunaan industri khususnya pada pembangkit listrik tenaga uap. Dalam pemeliharaan pompa, perusahaan dapat meminimalkan tingkat kegagalan, dapat meningkatkan standar kualitas dan membantu proses produksi berjalan sesuai dengan yang direncanakan.

\subsection{Perawatan dan Perbaikan Pompa Sentrifugal 800LC-38A}

Perawatan dan perbaikan adalah menghindarkan atau memperbaiki mesin atau komponen-komponennya dari kerusakan, dengan tindakan ini mesin dapat dioperasikan lagi. Kegiatan yang dilakukan diantaranya mengganti atau memperbaiki alat-alat mesin yang bertujuan agar mesin dapat dioperasikan kembali sebagaimana mestinya. Kualitas dalam perbaikan harus diukur, jika kualitas perbaikan komponen mesin mempunyai $90-100 \%$ maka perbaikan yang dilakukan nilainya adalah baik sekali. 


\subsection{Perawatan Komponen-Komponen Utama Pompa Sentrifugal 800LC-38A}

Kegiatan pertama dilakukannya perbaikan adalah menganalisa terjadinya kerusakan, untuk mengetahuinya seorang tenaga perawatan dapat menggunakan panca indra atau dengan melihat, mendengar dan merasakan. Hal yang perlu dipersiapkan sebelum melakukan perbaikan adalah peralatan yang akan membantu dalam melaksanakan perbaikan. Setelah mengetahui kerusakan yang terjadi baru direncanakan perbaikannya. Dalam membuat rencana perbaikan harus berpegang pada prinsip ekonomis, misalnya tenaga, waktu dan ongkos perbaikan harus sedikit mungkin. Komponen-komponen utama Pompa Sentrifugal 800LC-38A adalah:

\subsubsection{Impeler}

Impeler menjadi bagian utama dari pompa ini. Impeler berfungsi untuk mengubah energi kinetis dari pompa menjadi energi kecepatan pada cairan yang dipompakan secara kontinyu, sehingga cairan pada sisi isap secara terus menerus akan masuk mengisi kekosongan akibat perpindahan dari cairan yang masuk sebelumnya. Sesuai desain impelernya pompa sentrifugal 800LC-38A ini ditekakankan untuk membangkitkan debit fluida (flow) yang tinggi.

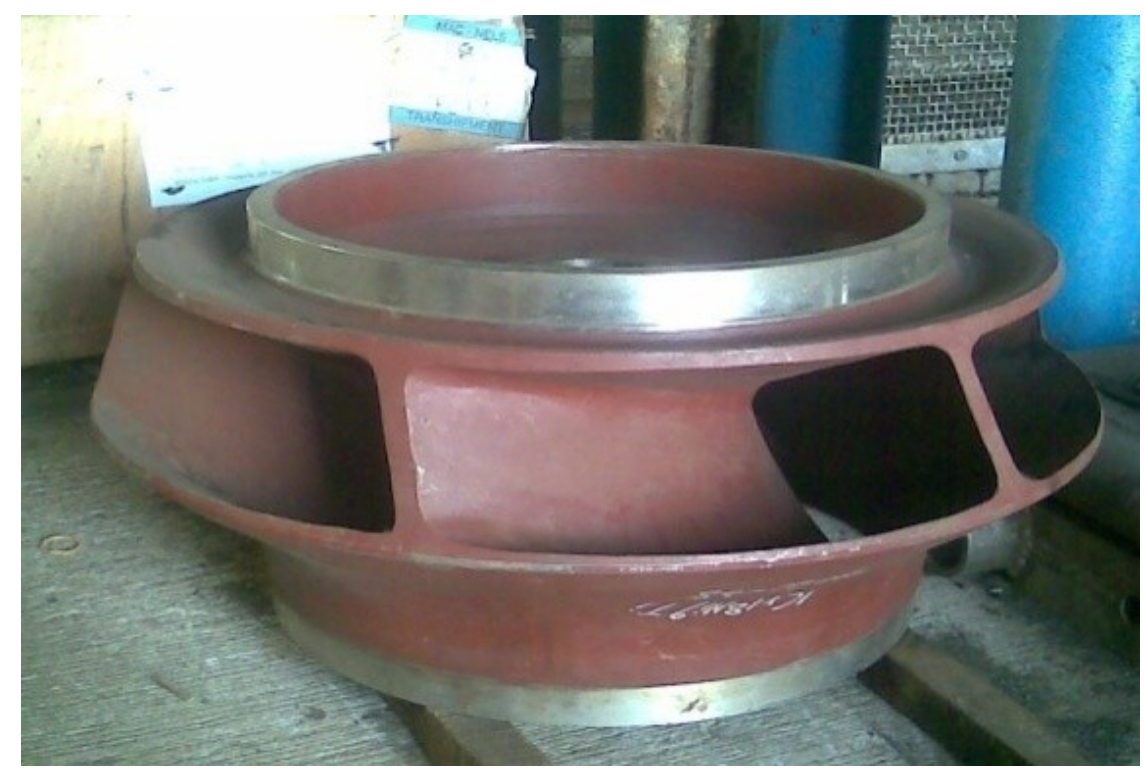

Gambar 3. Impeler Pompa Sentrifugal 800LC-38A

\subsubsection{Poros pompa/shaft}

Berfungsi untuk meneruskan putaran dari motor listrik/penggerak ke impeler selama beroperasi dan merupakan tempat kedudukan impeler dan bagian-bagian berputar lainnya. Shaft pompa sentrifugal 800LC-38A terbuat dari Baja Stainless. Baja Stainless adalah baja karbon dengan campuran kromium $10 \%$ sehingga lebih tahan terhadap karat. Pada pompa ini terdapat 3 buah shaft yaitu:

a. Driven Shaft (shaft yang langsung menerima putaran dari motor).

b. Middle Shaft (shaft bagian tengah pompa)

c. Impeller Shaft (shaft pada sisi inlet pompa dan tempat kedudukan impeler). 


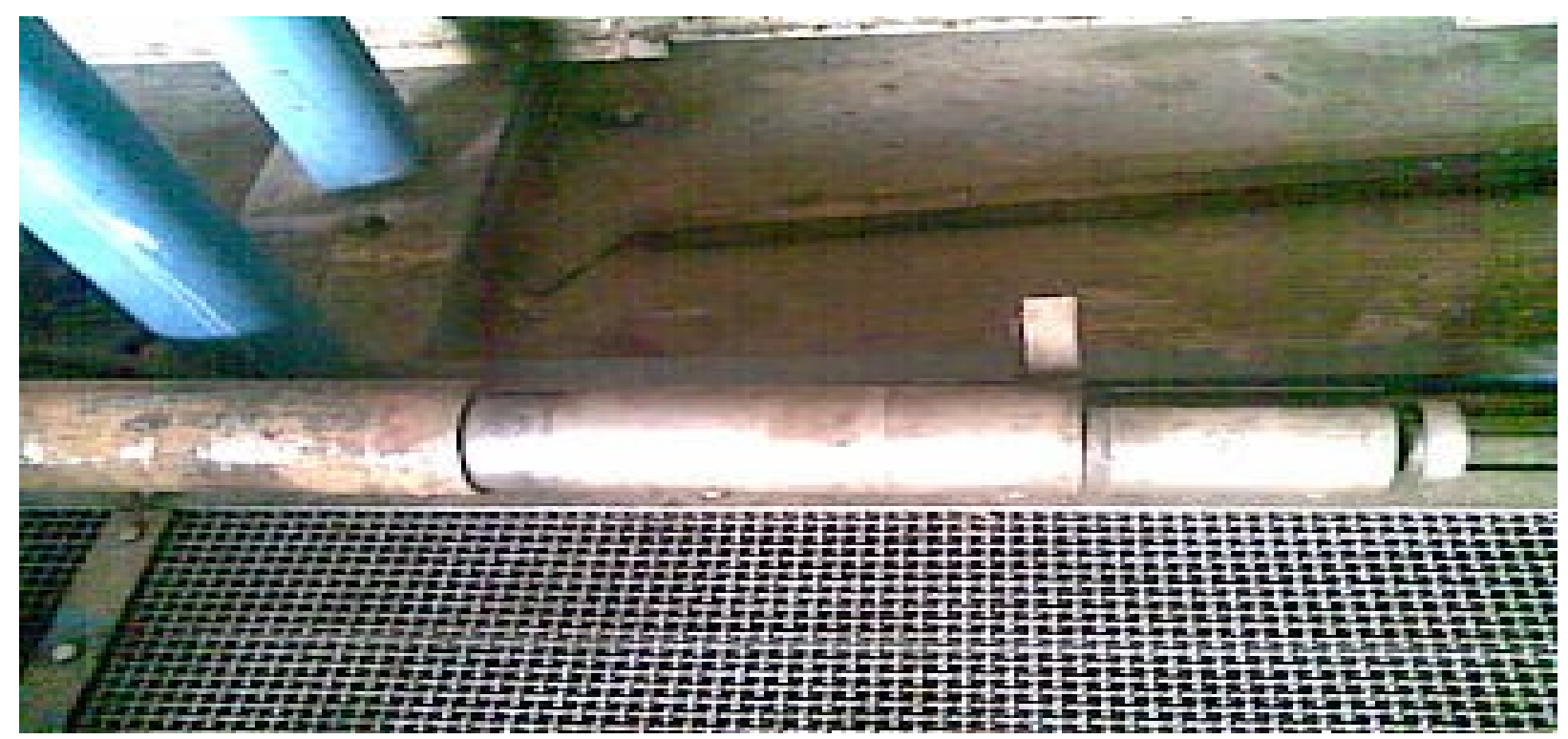

Gambar 4. Poros Pompa Sentrifugal 800LC-38A

\subsubsection{Teflon/Guide bearing}

Teflon/guide bearing berfungsi untuk menahan posisi poros agar tetap berada di garis sumbu kerjanya dan untuk melindungi poros dari erosi, korosi dan keausan dan sebagai bagian dari pencegahan kebocoran. Guide bearing yang terdapat pada pompa sentrifugal 800LC-38A terdiri dari:

a. Upper guide bearing: berada paling atas berfungsi sebagai penahan posisi poros dan mencegah kebocoran cairan pada poros penggerak (driven shaft). Guide bearing pada posisi ini disebut juga dengan gland packing karena fungsinya untuk menghindari kebocoran antara poros pompa dengan kasing shaft (guard column).

b. Middle guide bearing: pososisinya berada pada poros tengah (middle shaft) tepat dibawah adapter coupling penghubung poros penggerak dan poros bagian tengah pompa.

c. Lower guide bearing: berada di bawah adapter coupling penghubung poros tengah pompa dengan poros impeler (impeller shaft). 


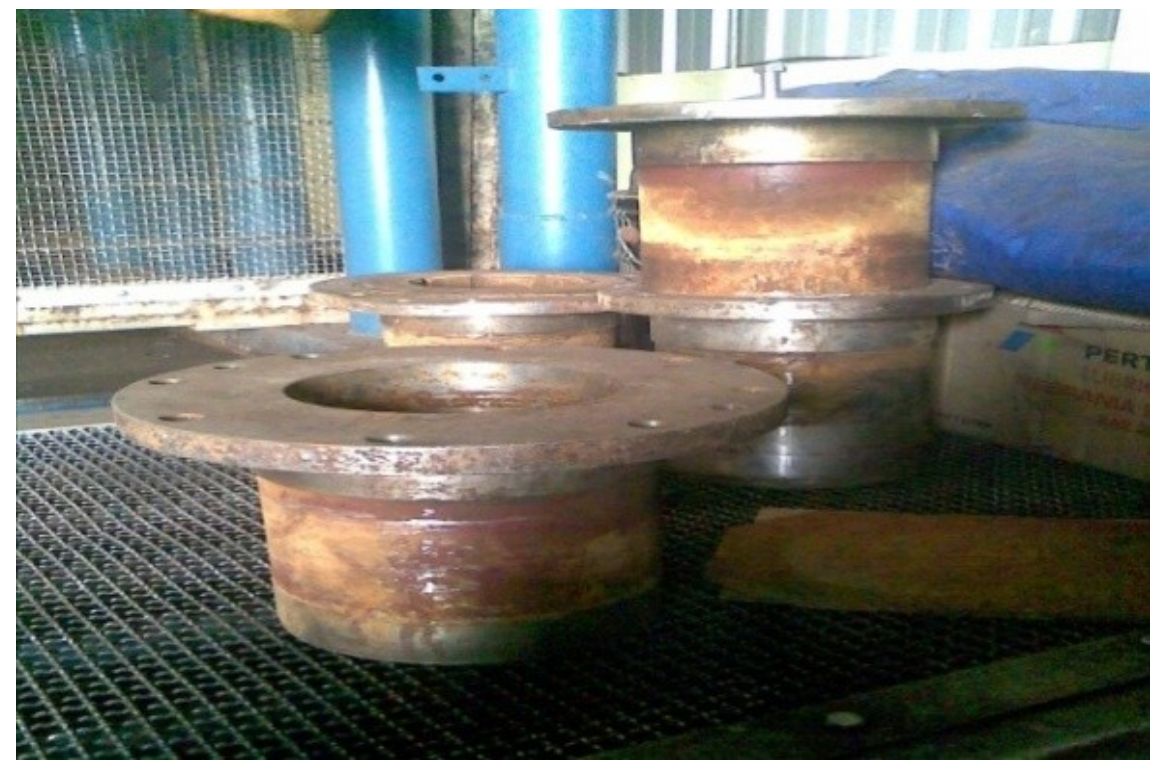

Gambar 5. Teflon/Guide Bearing pada Pompa Sentrifugal 800LC-38A

\subsubsection{Adapter Coupling}

Adapter coupling berfungsi sebagai penghubung kedua poros pompa. Posisi adapter coupling ini pada pompa yaitu berada diatas dari guide bearing/Teflon

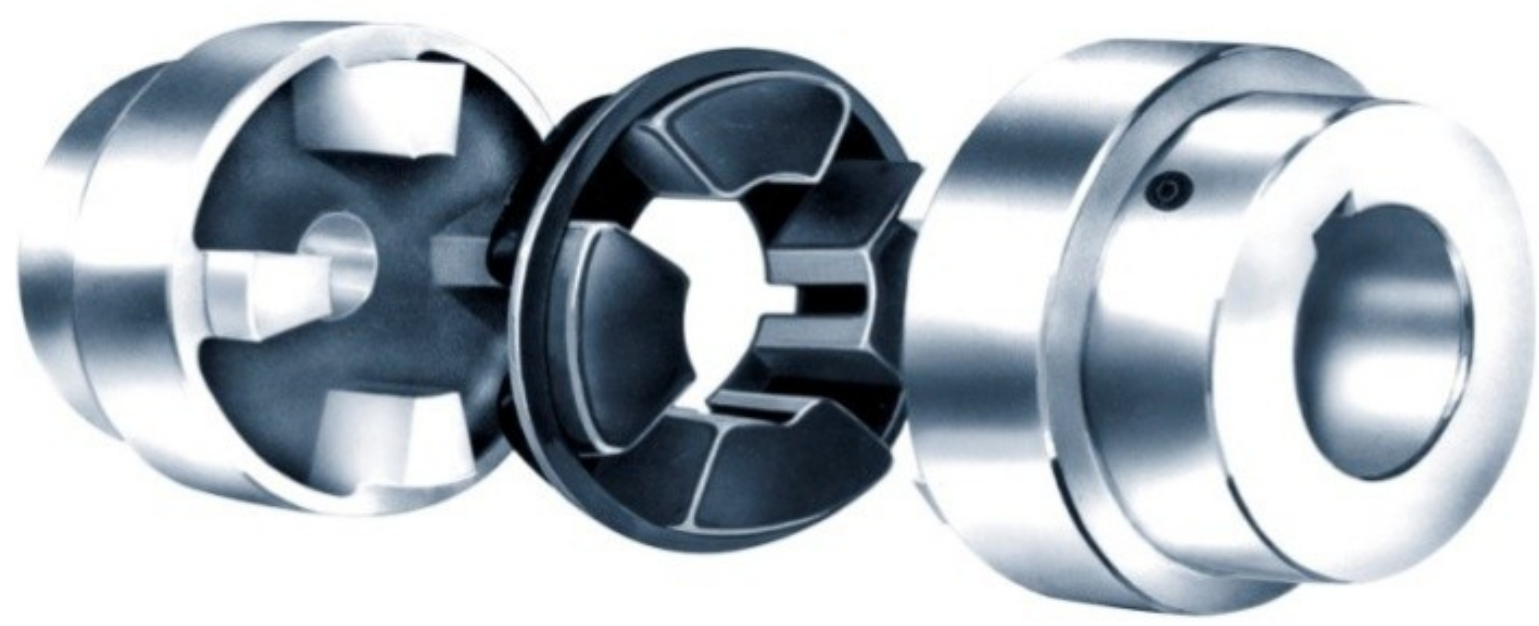

Gambar 6. Adapter Coupling

\subsubsection{Rigid Coupling}

Kopling berfungsi untuk menghubungkan dua poros dimana yang satu adalah poros penggerak dan yang lainnya adalah poros yang digerakkan. Didalam pemasangan kopling yang perlu diperhatikan adalah kesejajaran kopling pompa dengan kopling motor. Kopling yang digunakan pada pompa, bergantung dari desain sistem dan pompa itu sendiri. Untuk 
pompa ini menggunakan kopling kaku (rigid coupling), dimana kopling ini tidak mengizinkan terjadinya perubahan posisi kedua poros dan terlepas ketika beroperasi.

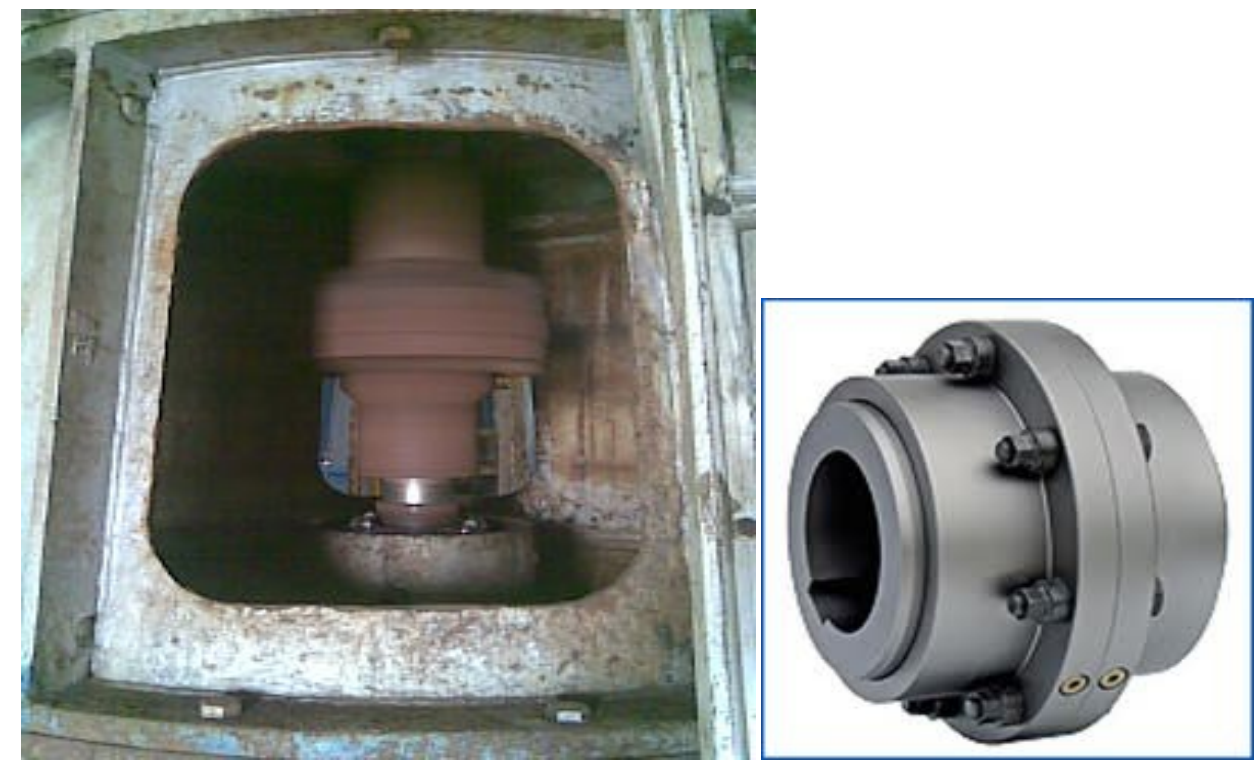

Gambar 7. Rigid Coupling pada Pompa Sentrifugal 800LC-38A

\subsubsection{Guard Column}

Adalah kasing dari poros pompa. Fungsinya adalah sebagai tempat kedudukan dari poros pompa serta untuk menjaga poros pompa dari kerusakan, korosi dan lainnya.

\subsubsection{Casing}

Merupakan bagian paling luar dari pompa yang berfungsi sebagai pelindung elemen yang berputar, tempat kedudukan pompa, serta tempat memberikan arah aliran dari impeler.

Casing pada pompa aksial berfungsi untuk menurunkan kecepatan pompa dan menaikkan tekanan kerjanya. Namun desainnya tidak seekstrim volute casing pada pompa sentrifugal, karena peningkatan tekanan outlet pompa aksial yang terlalu tinggi dapat menimbulkan vibrasi dan mengurangi umur kerja pompa aksial.

\subsubsection{Bantalan/Bearing}

Bantalan/bearing berfungsi untuk menumpu dan menahan beban dari poros agar dapat berputar, baik berupa beban radial maupun beban axial. Bearing juga memungkinkan poros untuk dapat berputar dengan lancar dan tetap pada tempatnya, sehingga kerugian gesek menjadi kecil.

Bearing pada motor penggerak terdiri dari:

a. Pada DE (Drive End): Deep Groove Ball Bearing 6334 C3.

b. Pada NDE (No Drive End): Angular Contact Thrust Ball Bearing 2x7334 BCBM DT (SKF) atau $2 \times 7334$ BUMPA DT (FAG). 
Alifurrahman, Zikri Hamdani, Darman Dapersal Dinar, Menhendry, Yuli Yetri
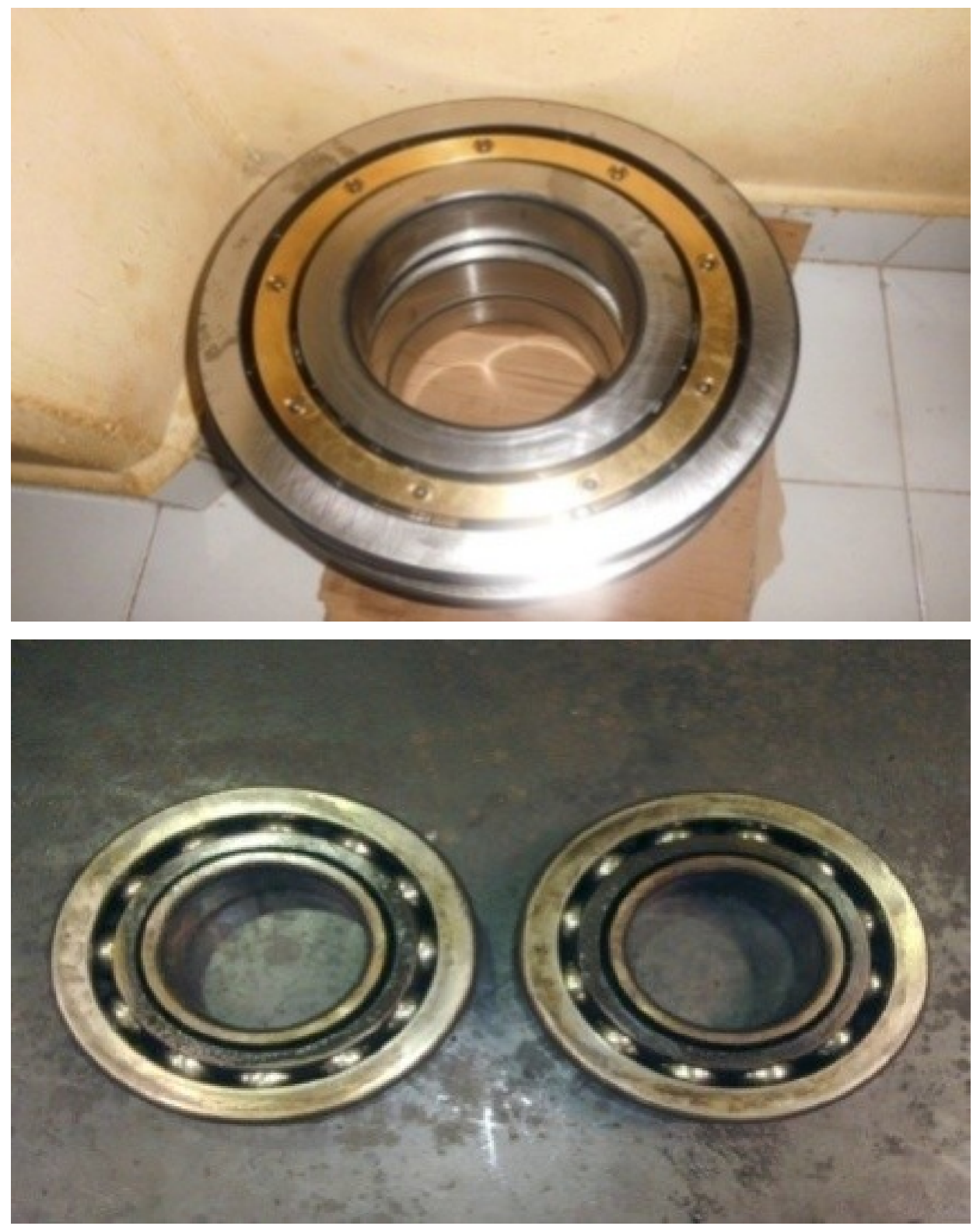

Gambar 8. Radial Bearing dan Trusht Bearing

\subsubsection{Penyaring/Strainer}

Berfungsi untuk menyaring kerang, lumut dan lumpur yang mungkin terangkat oleh impeler dan masuk kedalam saluran pompa. 


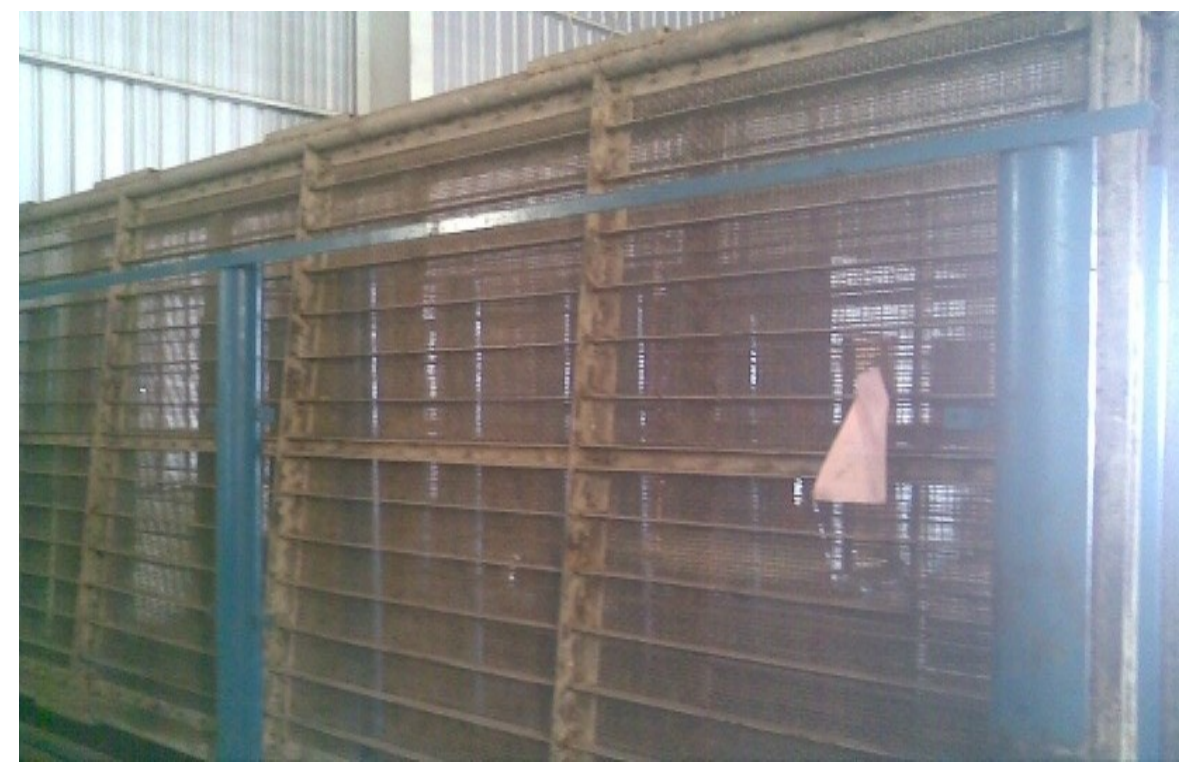

Gambar 9. Strainer/Penyaring pada Pompa Sentrifugal 800LC-38A

\subsubsection{Sistem lubrikasi}

Sistem lubrikasi pada pompa berfungsi untuk mengurangi koefisien gesek antara dua permukaan yang bertemu sehingga mengurangi resiko keausan. Lubrikasi pada pompa terutama digunakan pada bearing. Sistemnya pelumasan pada pompa sentrifugal 800LC-38A menggunakan sistem pelumasan grease.

\section{KESIMPULAN}

Berikut adalah kesimpulan yang dapat kita ambil setelah pembahasan laporan tugas akhir ini dan perawatan dan perbaikan pompa sentrifugal 800LC-38A adalah sebagai berikut:

a. Pompa Sentrifugal 800LC-38A merupakan pompa vertikal yang termasuk kedalam jenis pompa aliran aksial (fluida yang keluar dari pompa arahnya sejajar dengan fluida yang masuk pompa). Fungsi utama dari pompa sentrifugal 800LC-38A pada PLTU 2x15 MW yaitu: berfungsi sebagai media supply air untuk sirkulasi air pendingin pada PLTU.

b. Komponen utama pada pompa sentrifugal 800LC-38A adalah impeler dengan desain yang ditekakankan untuk membangkitkan debit fluida (flow) yang tinggi. Untuk poros/shaft terdiri dari driven shaft, middle shaft dan impeler shaft. Untuk menahan posisi poros agar tetap berada di garis sumbu kerjanya dan untuk melindungi poros dari erosi merupakan fungsi dari guide bearing yang terbuat dari teflon. Penghubung 2 buah poros pompa menggunakan komponen adapter coupling sementara itu untuk menghubungkan poros pompa dengan poros motoran menggunakan kopling kaku/rigid coupling.

c. Material pompa sentrifugal $800 \mathrm{LC}-38 \mathrm{~A}$ secara keseluruhan terbuat dari Baja Stainless (baja karbon) dengan campuran kromium 10\% sehingga lebih tahan terhadap karat karena sesuai dengan jenis fluida yang dipompakan yaitunya air laut yang mengandung korosif tinggi. Komponen yang terbuat dari baja stainless yaitu: poros pompa, impeler, kopling pompa dan rumah poros.

d. Kerusakan yang sering terjadi pada pompa sentrifugal 800LC-38A antara lain terjadi vibrasi pada pompa disebabkan oleh keausan pada bearing dikarenakan kurang maksimalnya pelumasan pada bearing, shaft yang rusak dikarenakan oleh kondisi bearing yang rusak berkelanjutan akibat kekurangan pelumasan sehingga menimbulkan 
misalignment pada pompa yang dapat merusak poros dan komponen lainnya, kebocoran pada gland packing juga disebabkan oleh kondisi Bearing yang rusak saat pompa beropersi dengan terus berkelanjutan sehingga menimbulkan vibrasi yang tinggi dan mempengaruhi putaran poros.

e. Pemeliharaan pada pompa sentrifugal bertujuan untuk menjaga pompa agar selalu dalam kondisi siap untuk beroperasi, memperpanjang usia kegunaan pompa dan untuk mencegah terjadinya oeverhou/pada pompa.

f. Pemeliharaan ramalan pada pompa dapat dilakukan dengan pengecekan temperatur bearing, pengecekan getaran/vibrasi dan pengisian/penggantian oil dan grease secara berkala.

g. Pengecekan temperatur bearing motoran pada pompa meliputi penegecekan bearing NDE (No Drive End) dan bearing DE (Drive End) pada motor penggerak. Pengecekan bearing yang dilakukan meliputi 3 posisi yaitu Ax (sejajar dengan poros), R1 dan R2 (tegak lurus poros).

\section{REFERENSI}

[1] ohn W.Dufour, William E.Nelson , "Centrifugal Pump Sourcebook", Mc Graw-Hill, Inc, 1992

[2] J.Lichtenstein,"A Method of Analyzing the Performance of Centrifugal Pumps," A.S.M.E, 1992 